\title{
Pseudo Infantile Refsum's Disease: Catalase- Deficient Peroxisomal Particles with Partial Deficiency of Plasmalogen Synthesis and Oxidation of Fatty Acids
}

\author{
P. AUBOURG, K. KREMSER, M. O. ROLAND, F. ROCCHICCIOLI, AND I. SINGH
}

INSERM U342, Hopital Saint V'incent de Paul, Paris 75014, France PP.A., F.R.): Department of Pediatrics, Medical University of South Carolina. Charleston, South Carolina 29425 /K.K., I.S.J: and

Biochemistry Department, Hopital Debrousse, Lyon 69322, France [M.O.R.]

\begin{abstract}
Zellweger syndrome, neonatal adrenoleukodystrophy, and infantile Refsum's disease are genetic disorders characterized by the virtual absence of catalasepositive peroxisomes and a general impairment of peroxisomal functions. Recent studies in these three disorders have provided morphologic evidence of peroxisomal "ghosts" of density $1.10 \mathrm{~g} / \mathrm{cm}^{3}$ that contain membrane proteins but lack a majority of the matrix enzyme activities. We report here the biochemical studies in a female infant with clinical features of infantile Refsum's disease whose liver and fibroblasts contained cytosolic catalase but no catalase-positive peroxisomes. Oxidation of phytanic and pipecolic acids was severely impaired, whereas oxidation of very-long-chain fatty acids and dihydroxyacetone phosphate acyltransferase activity were only partially decreased. Immunoblot analysis showed that the three peroxisomal $\beta$-oxidation enzymes (acyl-CoA oxidase, enoyl-CoA hydratase/3-hydroxyacyl-CoA dehydrogenase, and 3-ketoacyl-CoA thiolase) were detectable in liver tissues. The 3-ketoacyl-CoA thiolase was of the mature form (41 kD), in contrast with other peroxisomal disorders with multiple enzyme deficiencies. The majority of these peroxisomal enzyme activities were associated with two subcellular membrane vesicle fractions lacking catalase: one had the density of normal peroxisomes $\left(1.17 \mathrm{~g} / \mathrm{cm}^{3}\right)$, the other, yet undescribed, a lower density $\left(1.137 \mathrm{~g} / \mathrm{cm}^{3}\right)$. This suggests that peroxisomes (density $=1.17 \mathrm{~g} / \mathrm{cm}^{3}$ ) and structures with lower density (density $\left.=1.137 \mathrm{~g} / \mathrm{cm}^{3}\right)$ found in this patient's cultured skin fibroblasts, although lacking catalase, contained functional peroxisomal enzymes. This distinguishes this disorder from other disorders of peroxisome biogenesis. (Pediatr Res 34: 270-276, 1993)
\end{abstract}

\section{Abbreviations}

n-ALD, neonatal adrenoleukodystrophy

$\beta$-ketothiolase or thiolase, 3-ketoacyl-CoA thiolase

bifunctional enzyme, enoyl-CoA hydratase/3-hydroxyacylCoA dehydrogenase

VLCFA, very-long-chain fatty acid

DAB, diaminobenzidine

DHAP-AT, dihydroxyacetone phosphate acyltransferase

Received February 4, 1993; accepted April 19, 1993.

Correspondence: P. Aubourg, Inserm U342, Hopital Saint Vincent de Paul, 82 avenue Denfert Rochereau, 75014 Paris, France.

Supported by National Institutes of Health Grant NS-22576 (I.S.) and by the Association Française contre la Myopathie (P.A.).
RCDP, rhizomelic chondrodysplasia punctata IRD, infantile Refsum's disease

Peroxisomes are subcellular organelles that participate in the $\beta$-oxidation of long-chain fatty acids and VLCFA (1-3), the synthesis of plasmalogens (4), the oxidation of L-pipecolic acid $(5,6)$, and bile acid synthesis (7). In addition, peroxisomes contain catalase that degrades the $\mathrm{H}_{2} \mathrm{O}_{2}$ produced by various oxidases (8). Peroxisomes, like mitochondria, arise by growth and division of preexisting peroxisomes (9). All peroxisomal proteins studied so far are synthesized on free polyribosomes, then translocated into preexisting peroxisomes. Peroxisomal proteins are generally synthesized in their final size with two exceptions. The $\beta$-ketothiolase is synthesized as a $44-\mathrm{kD}$ precursor converted into a 41-kD mature enzyme, and the acyl-CoA oxidase is synthesized as a $72-\mathrm{kD}$ precursor converted into two subunits of 52 and $20 \mathrm{kD}$. In both cases, the proteolytic cleavage occurs inside peroxisomes (10).

The term "disorders of peroxisome biogenesis" refers to a group of inherited neurodegenerative disorders in which the structure and metabolic function(s) of peroxisomes are defective (reviewed in 9). Tissues from infants with cerebrohepatorenal syndrome (Zellweger syndrome), n-ALD, or IRD contain none or few catalase-containing peroxisomes with a normal morphology $(11,12)$. In these disorders, peroxisomes fail to be formed normally, leading to a generalized defect of the peroxisomal enzymes (9). RCDP differs from these disorders because peroxisomes are grossly normal in this disease and contain catalase. Moreover, only three peroxisomal functions are impaired (plasmalogen synthesis, oxidation of phytanic acid, and processing of $\beta$-ketothiolase) (13-15).

This article reports a study of peroxisomal enzyme activities in a patient with clinical features of IRD and absence of catalasecontaining peroxisomes in liver and fibroblasts. Western blot analysis demonstrated the presence of peroxisomal $\beta$-oxidation enzymes in the liver. The activities for oxidation of VLCFA and DHAP-AT were partially defective in fibroblasts. The peroxisomes from cultured skin fibroblasts had a bimodal distribution in the Nycodenz gradient: a small population with normal density $\left(1.17 \mathrm{~g} / \mathrm{cm}^{3}\right)$ and a major population of peroxisome-like structures with lighter density $\left(1.137 \mathrm{~g} / \mathrm{cm}^{3}\right)$. These two peroxisomal populations showed varying degrees of peroxisomal enzyme activities but lacked catalase. These lighter density peroxisome-like structures are physically and functionally distinct from the recently described peroxisomal membrane "ghosts" $(16,17)$ and w-particles (18). The disorder reported here is therefore different from other disorders of peroxisomal biogenesis. 


\section{MATERIALS AND METHODS}

Case report. The patient was a female infant born after an uneventful $42 \mathrm{wk}$ of gestation. The parents were not related. She weighed $3620 \mathrm{~g}$ at birth and no facial dysmorphism was noted. Cholestasis was present during the neonatal period. Bilateral hearing loss was noted at $2 \mathrm{y}$. The patient walked at $2 \frac{1}{2}$ y and could speak several words at 3 y. At $3 \frac{1}{2}$ y, clinical evaluation showed cerebellar ataxia, retinitis pigmentosa with extinguished electroretinogram, and peripheral neuropathy. Brain-stem auditory evoked responses showed severe dysfunction of central auditory pathways. Hepatomegaly was detected. Between $31 / 2$ and $8 \mathrm{y}$, she deteriorated slowly and lost most of her motor and language abilities. At $81 / 2$ y, weight was $30 \mathrm{~kg}$ and head circumference $54 \mathrm{~cm}$ (98th percentile). The patient had few spontaneous movements, brief visual fixation, and could still respond to her surroundings. She was not able to walk or to sit up. Other findings included quadriparesis with Babinski signs and ankle clonus, generalized hypotonia, severe pigmentary retinopathy, and hepatomegaly. A skeletal survey was normal. Aspartate transaminase and alanine transaminase were 0.55 and $0.43 \mu \mathrm{kat} / \mathrm{L}$, respectively (normal $<0.60 \mu \mathrm{kat} / \mathrm{L}$ ). A morning ACTH concentration was 18 $\mathrm{nmol} / \mathrm{L}$ (normal $<20$ ). Visual and brain-stem auditory evoked responses were normal. A computed tomography scan showed moderate cortical atrophy without demyelination. At $15 \mathrm{y}$ of age, her neurologic status has remained unchanged.

Materials and general methods. The sources of reagents were as follows: cell culture reagents were from Gibco Laboratories, Grand Island, $\mathrm{NY} ;\left[1-^{14} \mathrm{C}\right]$ phytanic acids $(55 \mathrm{mCi} / \mathrm{mmol}),\left[{ }^{12 s} \mathrm{I}\right]$ sodium iodide $(100 \mathrm{mCi} / \mathrm{mL})$, and $\left[\mathrm{U}-{ }^{14} \mathrm{C}\right]$ glycerol 3-phosphate (159 $\mathrm{mCi} / \mathrm{mmol}$ ) were from Amersham Corp., Arlington Heights, IL; perdeuterated DL-pipecolic acid was from MSD Isotopes Div., Montreal, Quebec, Canada; molecular weight markers for electrophoresis and protein A were from Sigma Chemical Co., St Louis, MO; Nycodenz was from Accurate Chemical and Scientific Corp., Westbury, NY; and rabbit antisera against purified rat liver peroxisomal acyl-CoA oxidase, enoyl-CoA hydratase/3-hydroxyacyl-CoA dehydrogenase (bifunctional enzyme), and 3-ketoacyl-CoA thiolase (19-21) were generously donated by Dr. Takashi Hashimoto, Shinshu University, Matsumoto, Japan. $\left[1-{ }^{14} \mathrm{C}\right]$ lignoceric acid was synthesized by treatment of n-tricosanoyl bromide with $\mathrm{K}^{14} \mathrm{CN}$ (15). All other reagents were of analytical grade and obtained from commercial sources.

A liver sample was obtained by needle biopsy at $81 / 2$ y. Electron microscopy of liver tissue was performed as reported previously (22), and catalase activity was stained cytochemically by the DAB method as described by Roels and Goldfischer (23). Catalase activity was assayed by the method of Peters et al. (24). The subcellular distribution of catalase (cytosolic or organelle-associated) was measured by disruption of fibroblasts with digitonin (25) and quantitation of catalase in gradient fractions (15).

Biochemical assay's of peroxisomal function. Levels of VLCFA were measured in the lipid fraction of plasma and cultured fibroblasts by gas-liquid chromatography-mass spectrometry (26). The capacity of the fibroblasts to oxidize $\left[1-{ }^{14} \mathrm{C}\right]$ lignoceric acid to acetate (water-soluble products) was measured as described previously (27). Briefly, the fatty acid substrate was solubilized with $\alpha$-cyclodextrine and added to the assay medium. The enzyme reaction was stopped with $1.25 \mathrm{~mL}$ of $1 \mathrm{M}$ potassium hydroxide in methanol, and the denatured protein was removed by centrifugation. The supernatant was incubated at $60^{\circ} \mathrm{C}$ for $1 \mathrm{~h}$, neutralized with acid, and partitioned with chloroform and methanol. The amount of radioactivity in the upper phase is an index of the amount of $1-{ }^{14} \mathrm{C}$-labeled fatty acid oxidized to acetate. For solubilization of the fatty acid substrate with $\alpha$-cyclodextrine, the fatty acid $\left(20 \times 10^{6} \mathrm{dpm}\right)$ was first dried in a tube under nitrogen and then resuspended in $3.5 \mathrm{~mL}$ $\left(20 \mathrm{mg} / \mathrm{mL}\right.$ ) of $\alpha$-cyclodextrine by sonication for $1 \mathrm{~h}$ at $4^{\circ} \mathrm{C}$. The sp act of $\left[1-{ }^{14} \mathrm{C}\right]$ lignoceric acid used in fibroblast subcellular fractions and homogenates was 52 and $57 \mathrm{mCi} / \mathrm{mmol}$, respectively.

The peroxisomal steps of plasmalogen biosynthesis were assayed in fibroblasts by the double label, double substrate method (28), and the activity of DHAP-AT was measured according to the procedure described previously $(29,30)$. For substrate (dihydroxyacetone phosphate) synthesis, the reaction mixture contained $10 \mu \mathrm{Ci}\left[\mathrm{U}-{ }^{14} \mathrm{C}\right.$ ]glycerol 3-phosphate (sp act $156 \mathrm{mCi} /$ $\mathrm{mmol}$ ), $0.6 \mathrm{mM}$ glycerol-3-phosphate, $5 \mathrm{mM}$ pyruvate, $1 \mathrm{mM}$ $\mathrm{NAD}^{+}$, lactate dehydrogenase (10 units), $\alpha$-glycerol-3-phosphate dehydrogenase (10 units), and $50 \mathrm{mM}$ triethanolamine buffer, $\mathrm{pH}$ 7.6. After $60 \mathrm{~min}$ of incubation at $25^{\circ} \mathrm{C}$, the reaction was stopped by the addition of an equal volume of chloroform and, after mixing vigorously, the upper phase containing $\left[\mathrm{U}-{ }^{14} \mathrm{C}\right]$ dihydroxyacetone phosphate was transferred to another set of tubes. Under these conditions, the conversion of $\left[\mathrm{U}-{ }^{14} \mathrm{C}\right]$ glycerol 3-phosphate to $\left[\mathrm{U}-{ }^{14} \mathrm{C}\right]$ dihydroxyacetone phosphate was quantitative (30). For assay of DHAP-AT activity, a reaction mixture containing $0.1 \mathrm{mM}\left[\mathrm{U}-{ }^{14} \mathrm{C}\right.$ ]dihydroxyacetone phosphate, $8 \mathrm{mM} \mathrm{MgCl}, 8 \mathrm{mM}$ sodium fluoride, $0.4 \mathrm{mg}$ albumin, $0.15 \mathrm{mM}$ palmitoyl-CoA, and $75 \mathrm{mM}$ acetate buffer, $\mathrm{pH}$ 5.4 , in $0.12 \mathrm{~mL}$ was incubated at $37^{\circ} \mathrm{C}$ for $2 \mathrm{~h}$. The reaction was stopped with $0.45 \mathrm{~mL}$ of chloroform:methanol (1:2), $150 \mu \mathrm{L}$ of chloroform, and $150 \mu \mathrm{L} 2 \mathrm{M} \mathrm{KCl} / 0.2 \mathrm{M} \mathrm{H}_{3} \mathrm{PO}_{4}$. The lower phase $(200 \mu \mathrm{L})$ was applied to filter papers (Whatman $3 \mathrm{MM}$ ). which were dried at room temperature and then washed with 20 $\mathrm{mL}$ of $10 \%, 10 \mathrm{~mL}$ of $5 \%$, and $10 \mathrm{~mL}$ of $1 \%$ trichloroacetic acid, respectively. Filter papers were dried overnight and the radioactivity was counted.

Plasma levels of phytanic acid were measured by gas-liquid chromatography-mass spectrometry (26) and $\alpha$-oxidation of phytanic acid by fibroblasts was determined by the method of Poulos et al. (31). The concentrations of the bile acid intermediates, trihydroxycoprostanoic acid and dihydroxycoprostanoic acid, were determined by the method of Bjorkhem and Falk (32). L-Pipecolic acid was measured in serum using gas chromatography-mass spectrometry by a stable isotope dilution method (33).

Subcellular fractionation of cultured fibroblasts. Skin fibroblasts were grown to confluency in $75-\mathrm{cm}^{2}$ dishes, and 30 or more confluent flasks were harvested by mild trypsinization and incubated for $1 \mathrm{~h}$ as a suspension in Dulbecco's modified Eagle medium supplemented with $15 \% \mathrm{FCS}$ at $37^{\circ} \mathrm{C}$. After centrifugation, cell pellets were washed with homogenizing medium $(0.25$ $\mathrm{M}$ sucrose, $1 \mathrm{mM}$ EDTA, $1 \mu \mathrm{g} / \mathrm{mL}$ antipain, $0.7 \mu \mathrm{g} / \mathrm{mL}$ leupeptin, $0.2 \mathrm{mM}$ phenyl methylsulfonylfluoride, $0.1 \%$ ethanol, and 3 $\mathrm{mM}$ imidazole buffer, $\mathrm{pH}$ 7.4) and subfractionated by differential and isopyknic density gradient using Nycodenz as described previously (27). Subcellular fractions containing different organelles were identified by appropriate marker enzymes: catalase for peroxisomes (34); cytochrome $c$ oxidase for mitochondria (35) and NADPH-cytochrome $c$ reductase for microsomes (36). The protein concentrations were measured by the procedure of Bradford (37).

Immunoblot analysis of peroxisomal proteins. Liver homogenates were analyzed by SDS-PAGE and immunoblotting as previously described, using antisera against the peroxisomal fatty acid $\beta$-oxidation enzymes (38).

\section{RESULTS}

Electron microscopy of liver biopsy and fibroblasts. Bile canaliculi were dilated with membranous deposits filling the lumen. The cytoplasm of mesenchymal cells contained inclusions with spikelike protrusions. The light or dense matrix of these cells contained osmiophilic globules with abundant rectilinear trilamellar structures (not shown). The hepatocytes contained numerous dark bodies, generally located near bile canaliculi, and rare trilamellar structures were sometimes present. Normal catalase-positive peroxisomes were not demonstrable with DAB staining technique in liver and fibroblasts (not shown). 
Biochemical studies of peroxisome structure and function. The results of these assays are presented in Table 1. VLCFA levels were elevated in plasma but much less in cultured fibroblasts compared with Zellweger syndrome, n-ALD, or IRD (Table 1) $(39-41) . \beta$-Oxidation of VLCFA in cultured fibroblasts was decreased (64\% of control values) but less than in Zellweger, $n$ ALD or IRD cells (Table 1) (39-41). Bile acid intermediates (trihydroxycoprostanoic acid and dihydroxycoprostanoic acid), which are not normally detectable in urine, were found in the patient's urine but not in the plasma. Phytanic acid oxidation was markedly decreased in fibroblasts, and plasma levels of phytanic acid were elevated. The pipecolic acid level in serum was largely increased. In contrast to Zellweger syndrome and nALD, plasmalogen biosynthesis was normal in fibroblasts (Table 1), although DHAP-AT activity was decreased ( $42 \%$ of control values). This decrease was less severe than in patients with Zellweger syndrome, n-ALD, or IRD (Table 1). Catalase was found in normal amount in fibroblasts from this patient. Total $\mathrm{sp}$ act of catalase was $10.7 \pm 1.4 \mathrm{mU} / \mathrm{mg}$ compared with $8.5 \pm$ $1.6 \mathrm{mU} / \mathrm{mg}$ in control fibroblasts. However, the subcellular distribution of catalase in the patient's fibroblasts was abnormal. After digitonin-disruption of control fibroblasts, more than $90 \%$ of the catalase was sedimentable at $12000 \times \mathrm{g}$ for $10 \mathrm{~min}$, indicating that it was contained in the peroxisomes. In contrast, the majority (94\%) of catalase in the patient's fibroblasts was not sedimentable, indicating that it was free in the cytoplasm.

Immunoblot analysis of peroxisomal $\beta$-oxidation enzymes in liver. Immunoblotting showed the presence of all three peroxisomal $\beta$-oxidation enzymes in the patient's liver (Fig. 1). The bifunctional enzyme was present in amounts similar to those in the control, as shown by the similar intensity of staining of the band in the immunoblot. The $52 \mathrm{kD}$ and $21 \mathrm{kD}$ subunits of acyl$\mathrm{CoA}$ oxidase were present in decreased amounts and the $72-\mathrm{kD}$ subunit was not detected. The $\beta$-ketothiolase immunoreacted as a $41-\mathrm{kD}$ molecular size protein, indicating that the enzyme was present in the mature processed form, in amounts similar to those in the control. These results demonstrate that the distribution of $\beta$-oxidation enzymes in the liver of the patient is completely different from that of patients with disorders of the biogenesis of peroxisomes (Fig. 1, lanes 2 and 5) (38). Thus, despite the absence of catalase-containing peroxisomes in the patient's tissues, peroxisomal $\beta$-oxidation enzymes were detectable immunologically in the liver.

Enzlime activities in different subcellular fractions from cultured skin fibroblasts. Subcellular organelles from control and patient cultured skin fibroblasts were prepared in Nycodenz gradients by a procedure described previously by our laboratory (27). The distribution of marker enzymes for different organelles and the enzyme activities of DHAP-AT, acyl-CoA oxidase, and oxidation of lignoceric acid are shown in Figure 2. As judged by the marker enzymes for different organelles in the gradient (catalase for peroxisomes, NADPH-cytochrome $c$ reductase for microsomes, and cytochrome $c$ oxidase for mitochondria), these organelles were easily distinguished from each other in the gradient from control cultured skin fibroblasts. Although the distribution of cytochrome $c$ oxidase (mitochondria) and NADPHcytochrome $c$ reductase (microsomes) was normal in this patient, catalase was found only in the soluble fraction at the top of gradient instead of the peroxisomal fraction density $\left(1.17 \mathrm{~g} / \mathrm{cm}^{3}\right)$ at the bottom of the gradient (Fig. $2 A$ ). These results confirm the findings of digitonin treatment (Table 1) that almost all of the catalase in this patient was confined to the subcellular compartment, cytosol, a pattern observed in other disorders of peroxisomal biogenesis (e.g. Zellweger syndrome, n-ALD, and IRD). In agreement with our previous studies (27), the enzyme activities for DHAP-AT, acyl-CoA oxidase, and oxidation of lignoceric acid in a gradient from control fibroblasts were only found in peroxisomal peak (density $=1.17 \mathrm{~g} / \mathrm{cm}^{3}$ ) (Fig. $2 B$ ). In the gradient from this patient, these enzyme activities were observed in the peroxisomal peak with normal density $\left(1.17 \mathrm{~g} / \mathrm{cm}^{3}\right)$ and in the mitochondrial peak (density $=1.137 \mathrm{~g} / \mathrm{cm}^{3}$ ), suggesting that the peroxisomal peak and the mitochondrial peak of this patient, although lacking catalase, contained peroxisomal enzyme activities (Fig. 2B). The specific activities for DHAP-AT, acyl-CoA oxidase, and the oxidation of lignoceric acid in the peroxisomal peak and mitochondrial peak containing peroxisomal activities are shown in Table 2 . The specific activity of DHAP-AT in the normal peroxisomal peaks (density $=1.17 \mathrm{~g} / \mathrm{cm}^{3}$ ) from control

Table 1. Biochemical assessment of peroxisome function*

\begin{tabular}{|c|c|c|c|c|c|}
\hline & Patient & Control & n-ALD & Zellweger syndrome & IRD \\
\hline Plasma C26:0 $(\mu \mathrm{mol} / \mathrm{L})$ & 2.85 & $0.35 \pm 0.19(400)$ & $3.71 \pm 1.66(10) \dagger$ & $5.88 \pm 1.59(15) \dagger$ & $2.39 \pm 0.85(4) \dagger$ \\
\hline Fibroblast C26:0/C22:0 & $0.148 \pm 0.027$ & $0.08 \pm 0.04(60)$ & $0.87 \pm 0.35(10) \dagger$ & $1.16 \pm 0.51(15) \dagger$ & $0.62 \pm 0.38(4) \dagger$ \\
\hline Plasma phytanic acid $(\mu \mathrm{mol} / \mathrm{L})$ & 49 & $2.05 \pm 0.65(400)$ & $7 / 10 \dagger \ddagger$ & $8 / 15+\ddagger$ & $35 \pm 16(4) \dagger$ \\
\hline \multicolumn{6}{|l|}{ Bile acid intermediates } \\
\hline Urine THCA $(\mu \mathrm{mol} / \mathrm{L})$ & 1.05 & $<0.1(20)$ & $1.45 \pm 0.65(5) \dagger$ & $0.65 \pm 0.30(5) \dagger$ & $0.80 \pm 0.35(2) \dagger$ \\
\hline Urine DHCA $(\mu \mathrm{mol} / \mathrm{L})$ & 1.25 & $<0.1(20)$ & $2.8 \pm 2.2(5) \dagger$ & $2.9 \pm 2.3(5) \dagger$ & $1.2 \pm 0.7(2) \dagger$ \\
\hline Serum pipecolic acid $(\mu \mathrm{mol} / \mathrm{L})$ & 45.2 & $1.5 \pm 0.6(20)$ & $55.0 \pm 26.6(10) \dagger$ & $25.4 \pm 13.9(15) \dagger$ & $27.3 \pm 12.7(4) \dagger$ \\
\hline $\begin{array}{l}\text { Fibroblast phytanic acid oxidation } \\
\qquad(\mathrm{pmol} / \mathrm{h} / \mathrm{mg} \text { protein })\end{array}$ & $5 \pm 2$ & $101 \pm 30(10)$ & $4.4 \pm 4.0(5) \dagger$ & $4.5 \pm 3.5(5) \dagger$ & $6.5 \pm 4.3(4) \dagger$ \\
\hline $\begin{array}{l}\text { Fibroblast plasmalogen synthesis } \\
\qquad\left({ }^{3} \mathrm{H} /{ }^{14} \mathrm{C}\right)\end{array}$ & $0.76 \pm 0.10$ & $0.62 \pm 0.16(28)$ & $4.66 \pm 1.63(10) \S$ & $10.40 \pm 2.85(6) \S$ & ND\$ \\
\hline $\begin{array}{l}\text { Fibroblast DHAP-AT }(\mathrm{pmol} / \mathrm{h} / \mathrm{mg} \\
\text { protein) }\end{array}$ & $292 \pm 66$ & $699 \pm 50(60)$ & $67 \pm 31(10) \dagger$ & $30.2 \pm 18(15) \dagger$ & $106 \pm 43(4) \dagger$ \\
\hline $\begin{array}{l}\text { Fibroblast } \mathrm{C} 24: 0 \text { oxidation }(\mathrm{pmol} / \mathrm{h} / \\
\text { mg protein) }\end{array}$ & $57 \pm 12$ & $89 \pm 32(58)$ & $14.7 \pm 4.0(10) \dagger$ & $3.4 \pm 1.8(12) \dagger$ & $17.2 \pm 4.7(4) \dagger$ \\
\hline $\begin{array}{l}\text { Fibroblast catalase distribution } \\
\text { (\% sedimentable) }\end{array}$ & $6 \pm 4$ & $90 \pm 3(5) \|$ & $13.0 \pm 8.0(16) \|$ & $10.0 \pm 7.0(21) \|$ & $5(2) \Upsilon$ \\
\hline
\end{tabular}

* The results for patient's fibroblasts are mean \pm SD of duplicate tests; values are given as mean \pm SD for controls; number of subjects in parentheses. THCA, trihydroxycoprostanoic acid; DHCA, dihydroxycoprostanoic acid; ${ }^{3} \mathrm{H} /{ }^{14} \mathrm{C}$, ratio of $\left[9^{\prime}, 10^{\prime}-{ }^{3} \mathrm{H}\right]$ hexadecylglycerol to $\left[1-{ }^{14} \mathrm{C}\right]$ hexadecanol incorporation in plasmalogen biosynthesis; ND, no data.

$\dagger$ Data from F. Rocchiccioli and M. O. Rolland (unpublished results).

$\ddagger$ Patients with plasma phytanic acid level $>4 \mu \mathrm{mol} / \mathrm{L}$.

$\S$ Data from Watkins et al. (4I).

|| Data from Hoefler et al. (39).

I Data from Poll-The et al. (40). 

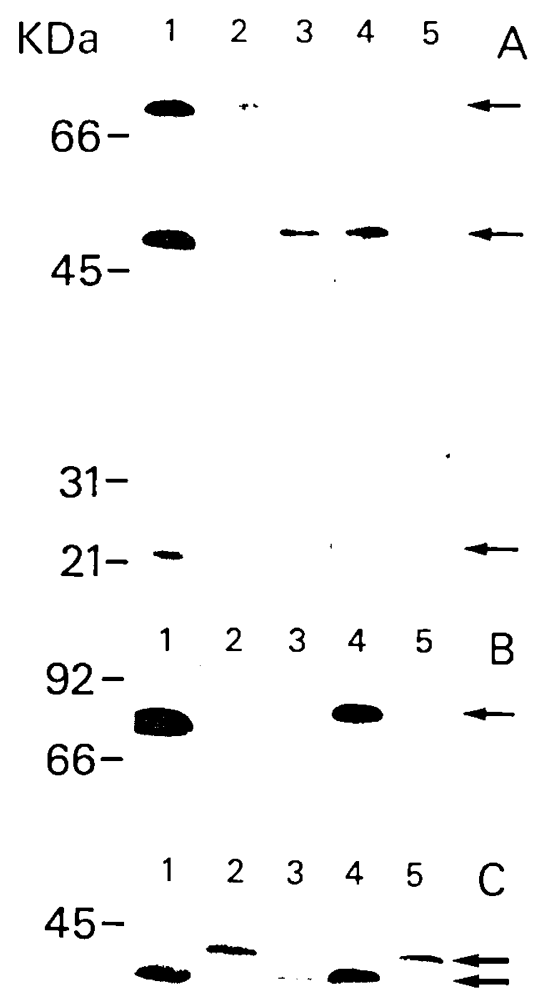

Fig. 1. Immunoblot analysis of peroxisomal $\beta$-oxidation enzymes in liver sample. Liver samples, stored at $-70^{\circ} \mathrm{C}$, were homogenized. The homogenates (about $5 \mu \mathrm{g}$ of protein) were analyzed for the presence of the peroxisomal $\beta$-oxidation enzymes acyl-CoA oxidase $(A)$, bifunctional enzyme $(B)$, and $\beta$-ketothiolase $(C)$ using antibodies against the purified rat liver enzymes. Lane 1, postmortem liver control; lane 2, liver sample from an n-ALD patient; lane 3, fetal tissue control; lane 4, liver biopsy from this patient; and lane 5, liver sample from a patient with Zellweger syndrome. The positions of molecular markers are at left. The positions of the $72 ; 52$; and $20-\mathrm{kD}$ acyl-CoA oxidase $(A)$, the $78-\mathrm{kD}$ bifunctional enzyme $(B)$, and the $44-\mathrm{kD} \beta$-ketothiolase precursor and the $41-\mathrm{kD}$ mature thiolase are indicated by arrows at the right.

fibroblasts was higher $(18.6 \pm 3.8 \mathrm{nmol} / \mathrm{h} / \mathrm{mg}$ protein $)$ than that from the patient $(4.1 \pm 1.3 \mathrm{nmol} / \mathrm{h} / \mathrm{mg}$ protein). However, the mitochondrial peak containing peroxisomal activities from the patient's fibroblasts had higher activity $(1.08 \pm 0.51 \mathrm{nmol} / \mathrm{h} / \mathrm{mg}$ protein) of DHAP-AT than the control mitochondria $(0.34 \pm$ $0.14 \mathrm{nmol} / \mathrm{h} / \mathrm{mg}$ protein) (Table 2). Similarly, the enzyme activities of acyl-CoA oxidase and the oxidation of lignoceric acid had lower activity in the normal peroxisomal peak (density = $1.17 \mathrm{~g} / \mathrm{cm}^{3}$ ) from the patient than in the peroxisomal peak (density $=1.17 \mathrm{~g} / \mathrm{cm}^{3}$ ) from control fibroblasts and the mitochondrial peak containing peroxisomal activities from the patient had higher activity than the mitochondrial peak from control fibroblasts (Table 2). Specific activity values of peroxisomal enzymes in the mitochondrial peaks were lower because of the relatively high mitochondrial and other protein content compared with peroxisomes in these fractions. These results suggest that, in this patient's fibroblasts, the majority of the peroxisomal enzyme activities (DHAP-AT, acyl-CoA oxidase, and the oxidation of lignoceric acid) are present in structures (density = $1.137 \mathrm{~g} / \mathrm{cm}^{3}$ ) that are lighter than normal peroxisomes and that these structures lack catalase.

\section{DISCUSSION}

The deficiency of peroxisomal functions observed in patients with disorders of peroxisomal biogenesis correlates with a lack of or a marked reduction in the number of peroxisomes in tissues and cultured skin fibroblast (9). Complementation analysis using somatic cell fusion showed that these disorders segregate into at least six different complementation groups $(42,43)$. This indicates that several gene products play a role in peroxisome biogenesis.

Although catalase-containing peroxisomes of normal appearance are absent in liver samples from patients with Zellweger syndrome, recent studies involving cell fractionation, immunofluorescence, and electron microscopy have provided evidence for the presence of aberrant empty peroxisomal membrane vesicles called peroxisomal membrane "ghosts," in which the peroxisomal integral membrane proteins $(22,36$, and $70 \mathrm{kD})$ have been identified $(16,17,25,44,45)$. The catalase in fibroblasts from patients with Zellweger syndrome was considered to be a cytosolic constituent. Recently, however, catalase has been localized in w-particles, membrane structures distinct from peroxisomal ghosts (18).

Our patient's liver lacks normal catalase-positive peroxisomes on the basis of DAB staining and electron microscopy. Catalase was found only in the cytosol of fibroblasts, and abnormalities in the metabolism of phytanic, pipecolic, and bile acids were clearly demonstrated (Table 1). The oxidation of VLCFA in fibroblasts was only mildly defective (64\% of control). This reduction may, however, be sufficient to impair VLCFA catabolism, as reflected by their accumulation in the patient's plasma. A comparable situation is observed in carriers of X-linked adrenoleukodystrophy $(46,47)$. DHAP-AT was moderately decreased without detectable impairment of plasmalogen synthesis in the fibroblasts from this patient.

The activities for the oxidation of VLCFA and DHAP-AT were associated with membrane fractions with density similar to normal peroxisomes $\left(1.17 \mathrm{~g} / \mathrm{cm}^{3}\right)$ and membrane fractions of lower density $\left(1.137 \mathrm{~g} / \mathrm{cm}^{3}\right)$. Although it is possible that peroxisomal proteins can be mistargeted to mitochondria, as in the case of alanine glyoxylate transferase (48), it seems unlikely that at least five proteins involved in two major metabolic pathways (synthesis of plasmalogens and oxidation of VLCFA) are incorporated in structures other than peroxisomes. The structures with lower density found in this patient's fibroblasts contained the majority of peroxisomal enzyme activities and are therefore likely peroxisome-like structures. Although we did not perform immunocytochemistry to characterize these particles, we can assume that they are different from the peroxisomal particles described in other disorders of peroxisome biogenesis. They had higher density $\left(1.137 \mathrm{~g} / \mathrm{cm}^{3}\right)$ than the membrane ghosts observed in Zellweger syndrome $\left(1.10 \mathrm{~g} / \mathrm{cm}^{3}\right)(16,17)$, and RCDP $(1.1-$ $\left.1.12 \mathrm{~g} / \mathrm{cm}^{3}\right)(13,15)$, and than w-particles $\left(1.13 \mathrm{~g} / \mathrm{cm}^{3}\right)(18)$. Another difference is that membrane ghost structures and $w$ particles in Zellweger syndrome or RCDP do not contain enzyme activities for DHAP-AT and oxidation of VLCFA $(15,18)$, whereas the peroxisome-like structures seen in our patient had significant activity for these enzymes. This indicates that the defect of peroxisome biogenesis observed in this patient is likely to be different from that reported in Zellweger syndrome, n-ALD, IRD, and RCDP.

Recent studies showed that the tripeptide sequence of Ser-LysLeu (PTS1) located near the C-terminal is an essential targeting signal for the import of proteins into peroxisomes (49). Immunoelectron microscopy and Western blot analysis revealed that anti-PTS1 antibody crossreacts only with proteins of the peroxisomal matrix, not with proteins of the peroxisomal membrane (50). This suggests that other topogenic signals are responsible for the incorporation of membrane proteins into peroxisomes. Recently, a second microbody targeting signal (PTS2) was identified in the first 11 amino acids of the precursor $\beta$-ketothiolase that encodes sufficient information to target this protein to peroxisomal matrix (51). Peroxisomal ghosts are able to import the unprocessed form of $\beta$-ketothiolase $(13,45)$, suggesting that the defect of peroxisomal protein import in Zellweger does not involve the PTS2 machinery. The proteolytic processing of this 
$P_{\text {CYTOCHROME C OXIDASE }}$
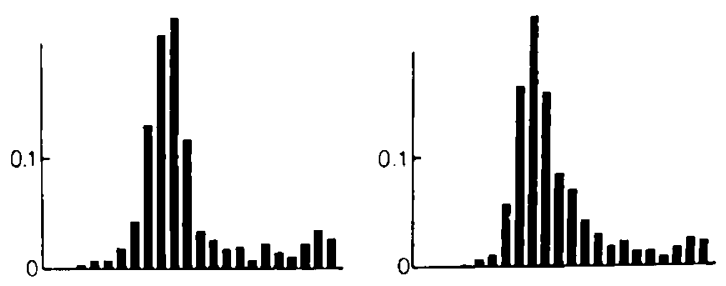

CYTOCHROME C REDUCTASE
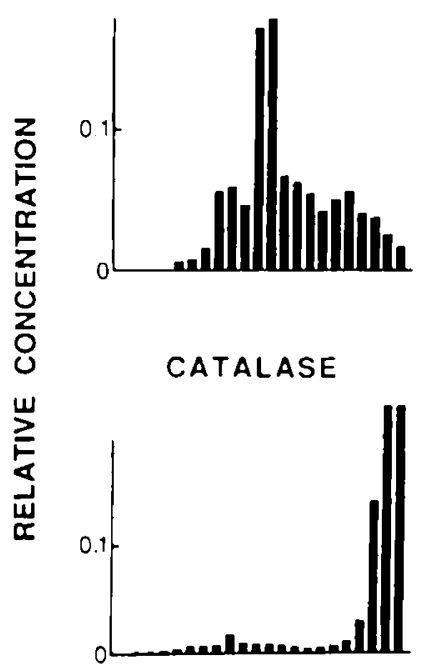

DENSITY

$\mathrm{g} \mathrm{ml}$

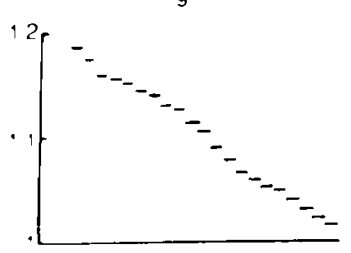

A
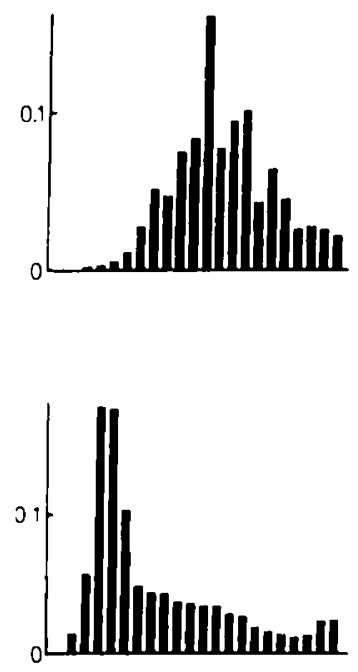

IR:ICTICNS

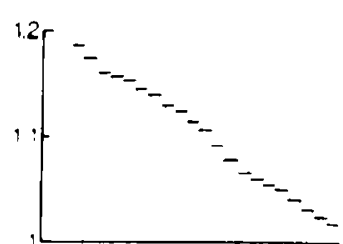

B

P

C24-Oxidation
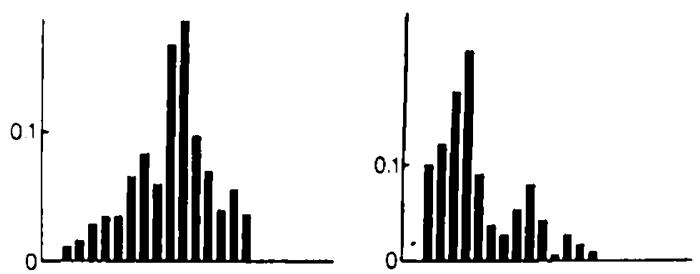

DHAP.AT
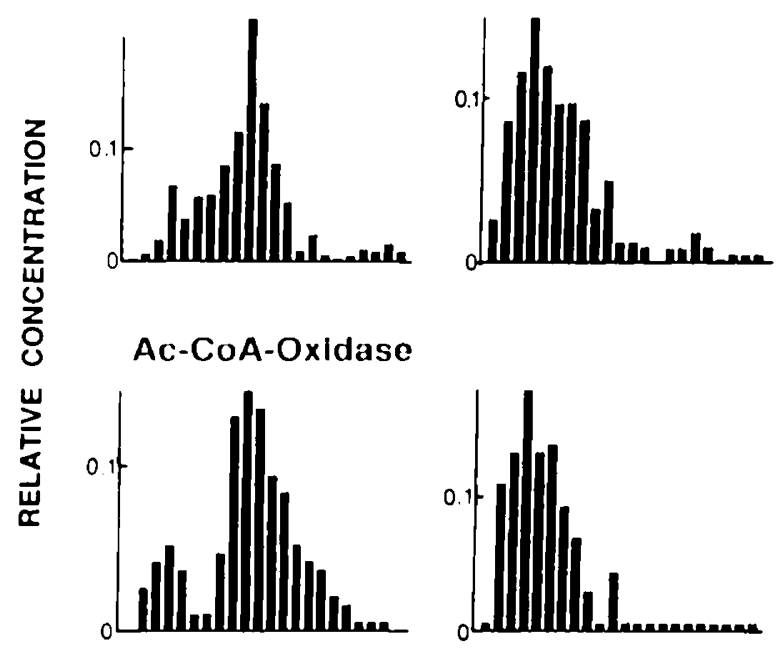

Proteln

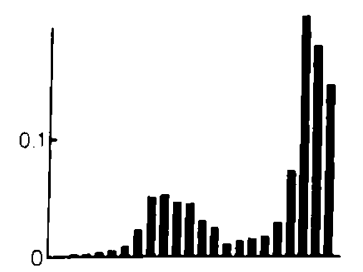

FRACTIONS

Fig. 2. Subcellular fractionation of cultured skin fibroblasts by a Nycodenz isopyknic gradient. The postnuclear fraction $(500 \times g$ for 5 min supernatant) from cultured skin fibroblasts of the control and from the patient were further fractionated with an isopyknic continuous gradient as described in the text. The distribution pattern of marker enzymes for different subcellular organelles $(A)$ and enzyme activities of DHAP-AT, acylCoA oxidase, and fatty acid oxidation $(B)$ are shown. $P$ represents the gradient profile of various enzyme activities of cultured skin fibroblasts from the patient and $C$ represents a similar distribution from cultured skin fibroblasts from the control.

Table 2. Specific activities (Nycodenz gradient) in peroxisomal peak and in mitochondrial peak containing peroxisome-like structures from patient and control fibroblasts*

\begin{tabular}{|c|c|c|c|}
\hline & $\begin{array}{l}\text { Acyl-CoA oxidase } \\
(\mu \mathrm{mol} / \mathrm{h} / \mathrm{mg} \text { protein })\end{array}$ & $\begin{array}{l}\text { Lignoceric acid oxidation } \\
(\mathrm{pmol} / \mathrm{h} / \mathrm{mg} \text { protein })\end{array}$ & $\begin{array}{c}\text { DHAP-AT } \\
\text { (nmol/h/mg protein) }\end{array}$ \\
\hline \multicolumn{4}{|c|}{ Peroxisomes (density $=1.170 \mathrm{~g} / \mathrm{cm}^{3}$ ) } \\
\hline Control & $15.2 \pm 5.8$ & $96 \pm 35$ & $18.6 \pm 3.8$ \\
\hline Patient & $4.08 \pm 1.32$ & $37 \pm 12$ & $4.1 \pm 1.3$ \\
\hline \multicolumn{4}{|c|}{$\begin{array}{l}\text { Peroxisome-like structures (density }=1.137 \\
\mathrm{~g} / \mathrm{cm}^{3} \text { ) }\end{array}$} \\
\hline Control & $0.25 \pm 0.14$ & $2.6 \pm 1.2$ & $0.34 \pm 0.14$ \\
\hline Patient & $1.20 \pm 0.25$ & $7.2 \pm 2.1$ & $1.08 \pm 0.51$ \\
\hline
\end{tabular}

\footnotetext{
* The results are mean $\pm \mathrm{SD}$ of duplicate tests on patient and control cell lines.
}

enzyme protein is, however, deficient in these particles. In our patient, the enzymes of peroxisomal matrix ( $\beta$-oxidation enzymes) and of peroxisomal membrane (DHAP-AT) were found active. This indicates that their import into peroxisomal structures did occur. The fact that $\beta$-ketothiolase was normally processed is consistent with the hypothesis that the corresponding protease is imported by a microbody-targeting signal pathway (51), possibly the PTS I pathway. Because several peroxisomal proteins using the PTS1 and PTS2 signals were imported in the peroxisome-like structures of our patient, we hypothesize that the defect of peroxisomal protein import involves neither of these signal machineries. 
In summary, this study demonstrates the presence of DHAP$\mathrm{AT}$, acyl-CoA oxidase, and other $\beta$-oxidation system enzymes in catalase-negative peroxisome-like structures of decreased density. We therefore propose that these particles represent immature forms of peroxisomes, intermediate between normal peroxisomes and peroxisomal ghosts. In addition, the marked defect in the metabolism of phytanic, pipecolic, and bile acids, compared with the partial deficiency of activities for DHAP-AT and VLCFA oxidation, distinguishes this patient's disorder from other peroxisomal disorders with multiple enzyme deficiencies: Zellweger syndrome, n-ALD, IRD, RCDP, and Zellweger-like syndrome. This disorder may therefore be a new peroxisomal disease.

Acknowledgments. The authors thank M. Odièvre for referring his patient; M. Fabre and M. Hadchouel for electron microscopy of the liver and fibroblasts; S. Hoefler and A. Moser for plasmalogen biosynthesis analysis; T. Hashimoto for his generous gift of antibodies to peroxisomal acyl-CoA oxidase, bifunctional enzyme, and $\beta$-ketothiolase; and P. F. Bougnères for reviewing the manuscript.

\section{REFERENCES}

1. Lazarow PB 1978 Rat liver peroxisomes catalyze the $\beta$-oxidation of fatty acids. J Biol Chem 253:1522-1528

2. Singh I, Moser AE, Goldfischer S, Moser HM 1984 Lignoceric acid is oxidized in the peroxisome: implications for the Zellweger cerebro-hepato-renal syndrome and adrenoleukodystrophy. Proc Natl Acad Sci USA 81:4203-4207

3. Singh H, Derwas N, Poulos A 1987 Very long chain fatty acid $\beta$-oxidation by rat liver mitochondria and peroxisomes. Arch Biochem Biophys 259: 382-390

4. Hajra AK, Bishop JE 1982 Glycerolipid biosynthesis in peroxisomes via the acyl-dehydroxyacetone phosphate pathway. Ann NY Acad Sci 386:170-182

5. Mihalik SJ, Rhead WJ 1989 L-Pipecolic acid oxidation in the rabbit and cynomolgus monkey: evidence for differing organellar locations and cofactor requirement in each species. J Biol Chem 264:2509-2517

6. Wanders RJA, Romeyn GJ, van Roermund CWT, Schutgens RBH, van den Bosch H, Tager JM 1988 Identification of L-pipecolate oxidase in human liver and its deficiency in the Zellweger syndrome. Biochem Biophys Res Commun 154:33-38

7. Kase F, Bjorkhem I, Pedersen JI 1983 Formation of cholic acid from $3 \alpha, 7 \alpha$, $12 \alpha$-thihydroxy- $5 \beta$-cholestanoic acid by rat liver peroxisomes. J Lipid Res 24:1560-1567

8. Tolbert NE 1981 Metabolic pathways in peroxisomes and glyosomes. Ann Rev Biochem 50:133-157

9. Lazarow PB, Moser HW 1989 Disorders of peroxisome biogenesis. In: Scriver CR, Baudet AL, Sly WS, Valle D (eds) The Metabolic Basis of Inherited Disease. McGraw-Hill, New York, pp 1479-1510

10. Hashimoto T 1992 Peroxisomal and mitochondrial enzymes. In: Tanaka K Coates PM (eds) New Developments in Fatty Acid Oxidation. Wiley-Liss, New York, pp 19-32

11. Goldfisher S, Moore CL, Johnson AB, Spiro AJ, Valsamis MP, Wisniewsk HK, Ritch RH, Norton WT, Rapin I, Gartner LM 1973 Peroxisomal and mitochondrial defects in the cerebro-hepato-renal syndrome. Science 182:62-64

12. Roels F, Espeel M, De Craemer D 1991 Liver pathology and immunocytochemistry in congenital peroxisomal diseases: a review. J Inherit Metab Dis 14:853-875

13. Balfe A, Hoefler G, Chen WW, Watkins PA 1990 Aberrant subcellular localization of peroxisomal 3-ketoacyl-CoA thiolase in the Zellweger syndrome and rhizomelic chondrodysplasia punctata. Pediatr Res 27:304-310

14. Heikoop JC, Van Roermund CWT, Just WW, Ofman R, Schutgens RBH, Heymans HSA, Wanders RJA, Tager JM 1990 Rhizomelic chondrodysplasia punctata: deficiency of 3-oxoacyl-coenzyme $A$ thiolase in peroxisomes and impaired processing of the enzyme. J Clin Invest 86:126-130

15. Singh I, Lazo O, Contreras M, Stanley W, Hashimoto T 1991 Rhizomelic chondrodysplasia punctata: biochemical studies of peroxisomes isolated from cultured skin fibroblasts. Arch Biochem Biophys 286:277-283

16. Santos MJ, Imanaka T, Shio H, Small GM, Lazarow PB 1988 Peroxisomal membrane assembly in Zellweger syndrome-aberrant organelle assembly. Science 239:1536-1538

17. Santos MJ, Imanaka T, Shio H, Lazarow PB 1988 Peroxisomal integral membrane proteins in control and Zellweger fibroblasts. J Biol Chem 263:10502-10509

18. Aikawa J, Chen WW, Kelley RI, Tada K, Moser HW, Chen GL 1991 Lowdensity particles (w-particles) containing catalase in Zellweger syndrome and normal fibroblasts. Proc Natl Acad Sci USA 88:10084-10088

19. Osumi T, Hashimoto T, Ui N 1980 Purification and properties of acyl-CoA oxidase from rat liver. J Biochem (Tokyo) 87:1735-1746
20. Furuta S, Miyazawa S, Osumi T, Hashimoto T, Ui N 1980 Properties of mitochondrial and peroxisomal enoyl-CoA hydratases from rat liver. $J$ Biochem (Tokyo) 88:1059-1070

21. Miyazawa S, Osumi T, Hashimoto T 1980 The presence of a new 3-oxoacylCoA thiolase in rat liver peroxisomes. Eur $\mathrm{J}$ Biochem 103.589-596

22. Aubourg P, Robain O, Rocchiccioli F, Dancea S, Scotto J 1985 The cerebrohepato-renal (Zellweger) syndrome: lamellar lipid profiles in adrenocortical, hepatic mesenchymal, astrocyte cells and increased levels of very long chain fatty acids and phytanic acid in the plasma. J Neurol Sci 69:9-25

23. Roels F, Goldfischer S 1979 Cytochemistry of human catalase: the demonstration of hepatic and renal peroxisomes by a high temperature procedure. J Histochem Cytochem 27:1471-1477

24. Peters TJ, Muller M, de Duve C 1972 Lysosomes of the arterial wall: isolation and subcellular fractionation of cells from normal rabbit aorta. J Exp Med $136: 1117-1139$

25. Lazarow PB, Fujiki Y, Small GM, Watkins P, Moser H 1986 Presence of the peroxisomal $22-\mathrm{kDa}$ integral membrane protein in the liver of a person lacking recognizable peroxisomes (Zellweger syndrome). Proc Natl Acad Sci USA 87:9193-9197

26. Aubourg P, Bougnères PF, Rocchiccioli F 1985 Capillary gas-liquid chromatography-mass spectrometric measurement of very long chain $\left(C_{22}\right.$ to $\left.C_{26}\right)$ fatty acids in microliter samples of plasma. J Lipid Res 26:263-267

27. Lazo O, Contreras M, Hashmi M, Stanley W, Irazu C, Singh I 1988 Peroxisomal lignoceroyl-CoA ligase deficiency in childhood adrenoleukodystrophy and adrenomycloneuropathy. Proc Natl Acad Sci USA 85:7647-7651

28. Roscher A, Molzer B, Bernheimer H, Stöckler S, Mutz I, Paltauf F 1985 The cerebrohepatorenal (Zellweger) syndrome: an improved method for the biochemical diagnosis and its potential value for prenatal detection. Pediatr Res 19:930-933

29. Schutgens RBH, Romeyn GJ, Wanders RJA, van den Bosch H, Schrakamp G, Heymans HSA 1984 Deficiency of acyl-CoA-dihydroxyacetone phosphate acyltransferase in patients with Zellweger (cerebro-hepato-renal) syndrome. Biochem Biophys Res Commun 120:179-184

30. Schutgens RBH, Romeyn GJ, Ofman R, van den Bosch H, Tager JM, Wanders RJA 1988 Acyl-CoA: dihydroxyacetonephosphate acyltransferase in human skin fibroblasts: study of its properties using a new assay method. Biochem Biophys Acta 879:286-291

31. Poulos A. Sharp P, Fellenberg AJ, Danks DM 1985 Cerebro-hepato-rena (Zellweger) syndrome, adrenoleukodystrophy and Refsum's disease: plasma changes and skin fibroblasts phytanic acid oxidase. Hum Genet 70:172-177

32. Bjorkhem I, Falk O 1983 Assay of the major bile acids in serum by isotope dilution-mass spectrometry. Scand J Clin Lab Invest 43:163-170

33. Rocchicioli F, Lepetit N, Aubourg P 1989 Determination of pipecolic acid in body fluids by chromatography-ammonia chemical ionization-mass spec trometry. Society for the Study of Inborn Errors of Metabolism 27th Annual Symposium, Munich, Germany, p 145(abstr)

34. Baudhu P, Beaufay Y, Li, Rehman O, Sellinger Z, Wattiaux R, Jacques $P$, de Duve C 1964 Tissue fractionation studies. Biochem J 92:179-184

35. Cooperstine SJ, Lazarow P 1971 Microspectrophotometric method for determination of cytochrome oxidase. J Biol Chem 189:655-670

36. Beaufay H, Amar-Cortesec A, Feytmans E. Thines-Sempous D. Wibo M, Rob M, Berthet T 1974 Analytical study of microsomes and isolated subcellular membranes from rat liver. $J$ Cell Biol 61:188-200

37. Bradford M $1976 \mathrm{~A}$ rapid and sensitive method for the quantification of microgram quantities of protein utilizing the principle of protein-dye binding. Anal Biochem 72:248-254

38. Guerroui S, Aubourg P, Chen WW, Hashimoto T, Scotto J 1989 Molecular analysis of peroxisomal $\beta$-oxidation enzymes in infants with peroxisomal disorders indicates heterogeneity of the primary defect. Biochem Biophys Res Commun 161:242-251

39. Hoefler G, Hoefler S, Watkins P, Chen WW, Moser A, Baldwin V, McGillivary B, Charrow J, Friedman JM, Ruledge L, Hashimoto T, Moser H 1988 Biochemical abnormalities in rhizomelic chondrodysplasia punctata. J Pediatr 112:726-733

40. Poll-The BT, Saudubray JM, Ogier HAM, Odièvre M, Scotto JM, Monnens L, Govaerts LCP, Roels F, Cornelis A, Schutgens RBH, Wanders RJA, Tager JM 1987 Infantile Refsum disease: an inherited peroxisomal disorder. Comparison with Zellweger syndrome and neonatal adrenoleukodystrophy. Eur J Pediatr 146:477-483

41. Watkins PA, Chen WW, Harris CJ, Hoefler G, Hoefler S, Blake DC, Balfe A, Kelley RI, Moser AB, Beard ME, Moser HW 1989 Peroxisomal bifunctional enzyme deficiency. J Clin Invest 83:771-777

42. Brul S, Waterfield A, Stijland A, Wanders RJA, Schram AW, Heymans HSA, Schutgens RBH, van der Bosch H, Tager JM 1988 Genetic heterogeneity in the cerebro-hepato-renal (Zellweger) syndrome and other inherited disorders with a generalized impairment of peroxisomal functions: a study using complementation analysis. J Clin Invest 81:1702-1710

43. Roscher AA, Hoefler S, Hoefler G, Paschke E, Paltauf F, Moser A, Moser H 1989 Genetic and phenotypic heterogeneity in disorders of peroxisome biogenesis: a complementation study involving cell lines from 19 patients. Pediatr Res 26:67-72

44. Wiemer EAC, Brul S, Just WW, Van Driel R, Brouwer-Kelder E, Van den 
Berg M, Weijers P, Schutgens RBH, Van den Bosch H, Schram A, Wanders RJA, Tager JM 1989 Presence of peroxisomal membrane proteins in liver and fibroblasts from patients with the Zellweger syndrome and related disorders: evidence for the existence of peroxisomal ghosts. Eur J Cell Biol 50:407-417

45. Van Roermund CWT, Brul S, Tager JM, Schutgens RBH, Wanders RJA 1991 cyl-CoA oxidase, peroxisomal thiolase and dihydroxyacetone phosphate acyltransferase: aberrant subcellular localization in Zellweger syndrome. J Inherited Metab Dis 14:152-164

46. Moser HW, Moser AE, Trojak JE, Supplee SW 1983 Identification of female carriers of adrenoleukodystrophy. J Pediatr 103:54-59

47. Singh I, Moser AE, Moser HW, Kishimoto Y 1984 Adrenoleukodystrophy: impaired oxidation of very long chain fatty acids in white blood cells, cultured skin fibroblasts, and amniocytes. Pediatr Res 18:286-290
48. Danpure CJ, Cooper PJ, Wise PJ, Jennings PR 1989 An enzyme trafficking defect in two patients with primary hyperoxaluria type 1 : peroxisomal alanine/glyoxolate amino transferase rerouted to mitochondria. J Cell Biol 108:1345-1352

49. Subramani S 1992 Targeting of proteins into peroxisomal matrix. J Membrane Biol 125:99-106

50. Keller GA, Krisans S, Gould SJ, Sommer JM, Wang CC, Schlicbs W, Kunau W, Brody S, Subramani S 1991 Evolutionary conservation of a microbody targeting signal that targets proteins to peroxisomes, glyoxysomes, and glycosomes. J Cell Biol 114:893-904

51. Swinkels BW, Gould SJ, Bodnar AG, Rachubinski RA, Subramani S 1991 A novel, cleavable peroxisomal targeting signal at the amino-terminus of the rat 3-ketoacyl-CoA thiolase. EMBO J 10:3255-3262 